\title{
庄内藩における鶴岡，湯田川，藤嶋の御茶屋について \\ OCHA-YA OF TSURUOKA, YUDAGAWA AND FUJISHIMA \\ IN SHONAI-HAN DURING EDO-ERA
}

岡田悟*, 飯淵康一**, 永井康雄***

Satoru OKADA, Kouichi IIBUCHI and Yasuo NAGAI

Tsuruoka was the capital of Shonai-Han. Yudagawa was a hot spring spot and Fujishima was a stage on the way from Tsuruoka to Edo. Ocha-ya was built in each town in Edo-Era. Through the examination of historical materials, following results are ascertained;

(1)The main part of Ocha-ya was composed of lord's rooms and retainer's rooms.

(2)Adjoining private house was attached to Ocha-ya and used as a cookroom.

(3)Yudagawa Ocha-ya was built for the use of the mission from the Central Covernment. Tsuruoka Ocha-ya was abolished because of financial difficulties of Shonai-Han.

Keywords: Ocha-ya, lodging, Shonai-Han, combination 御茶屋、休泊施設、庄内藩、結合型

\section{1.はじめに}

庄内藩内（図 1) には藩主、他藩大名、幕吏等の休泊施設として 様々な御茶屋が設けられ、これらの内、藩主参勤交代路にある清川、 および、温泉地の温海の御茶屋についてはすでに紹介している*1 、 ${ }^{* 22}$ 。両所の御茶屋の平面は、独立した敷地に御居間部分、番所広間 部分、台所部分から構成される点で共通していた。

今回対象とする鶴岡、湯田川、藤嶋の 3 箅所の内、藤嶋は藩主参 勤交代路にあるという点で清川と共通し、湯田川は温泉地という点 で温海に共通しており、共に御茶屋が設けられていた。また、庄内 藩主酒井氏の居館城下町である鶴岡には御使者宿があり、藩外の者 に利用されていた。御使者宿と呼ばれる施設は熊本城下にも見られ る $^{* 32}$ がこのような施設を対象として、平面構成にまで検討を加え た研究は、日杵の御客屋敷 ${ }^{* 4)}$ 等極めてわずかであり、今後数多くの 事例研究を蓄積する必要が痛感される。後に述べるようにこの御使 者宿は御茶屋とも呼ばれていた。

このようにこれら３箅所の御茶屋は、立地する場所の条件も、利 用方法もそれぞれ異なるが、これらの御茶屋に関する史料を検討し た結果、平面構成が極めて類似し、しかも、すでに発表した清川、 温海の御茶屋に共通して認められた構成とは大きく異なることが明 らかになったので、本稿で発表したい。

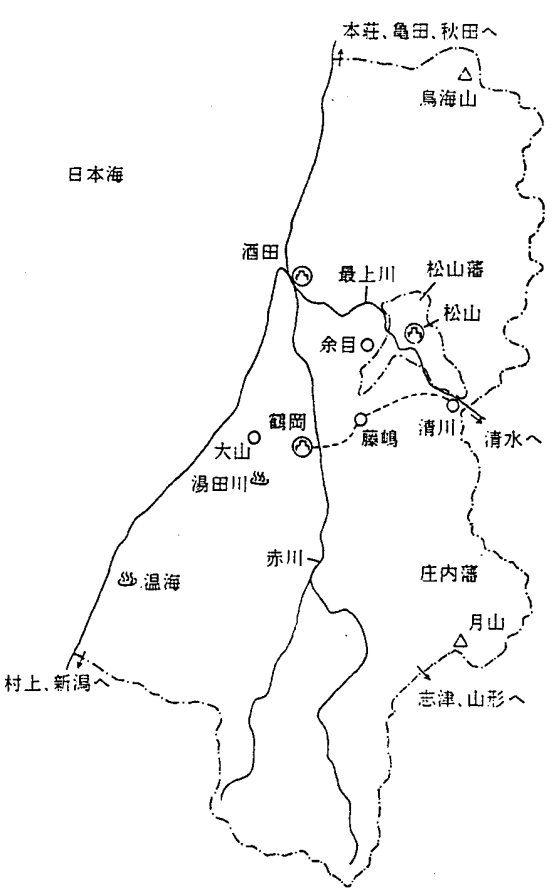

図 1 庄内藩略図
* 共立女子短期大学生活科学科 助教授・工博

** 東北大学大学院工学研究科都市・建築学専攻 教授・工博

**** 東北大学大学院工学研究科都市・建築学亚攻 講師・博士 (工学)
Assoc. Prof., Dept. of the Science of Living, Kyoritsu Women's Junior College, Dr. Eng.

Prof., Dept. of Architecture, Urban Planning and Building Engineering, Graduate School of Engineering, Tohoku Univ., Dr. Eng.

Lecturer, Dept. of Architecture, Urban Planning and Building Engineering, Graduate School of Engineering, Tohoku Univ., Dr. Eng. 


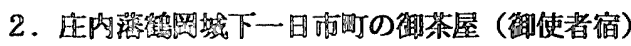

\section{2-1 鶴岡の概要と御茶屋（御使者宿）の位置。変遷}

元和 8 年 (1622) の入部以降明治維新まで、酒井氏居城は鶴岡に あり、藩は城下町支配のため町奉行を置き、その下に 2 名の大肝煎 を置いた。大肝煎は後に大庄屋之改称され、酒井氏入部以前から鶴 岡に在住した有力町人である宇治勘助、および、河上四郎右衛門の 両家がこの職を世襲していた。城下を通過する羽越街道には、主要 な町人町である荒町、下肴町、五日町、三日町、十日町、一日市町、 七日町、上有町、新町の 9 町が設けられ、城大手口を出ると三日町 に当る形になっていた（図2）。

数多く连されている鶴岡城下図にはいずれも一日市町西側の敷地 （図 2 ○印）に御使者宿の敷地が描かれており*5)、敷地の移動を示 す記録も見られない。また、敷地が色分けされている図では、御使 者宿は、町奉行所、評定所、蔵屋敷、武家地、寺院等と同じ色で塗 られ*6)、除地であったことが知られる。

これら絵図の中で、城下の様子を最も詳細に知ることができる享 保 4 年 (1719) 写元禄 9 年 (1696) 鶴岡城下大絵図（致道博物館蔵、 文献11）には、一日市町西側屋敷に御使者宿と、そして、その南降 に勘助と書き込まれている（図 3)。勘助は、先に述べた鶴岡町大 庄屋宇治家に当り、延宝 4 年（1676）の「一日市町御水帳」（文献 7、p. 541)に

- -、壱軒役 表口拾武間半裹地武拾五間 勘助居屋敷

一、壱軒役 表口九間裹地武拾五間 御使者宿」

\section{とある家に符合する。}

御使者宿に関して、文献で初見されるのは、寛文 5 年 (1665)の 「一日市町御使者宿、去辰極月類焼二付、御造立」（文献 $2 、 \mathrm{pp} .2$ 05）であり、寞文 4 年に御使者宿が焼失し、翌 5 年に再建されたこ 亡が知られる。この再建の記事は、御城、江戸屋敷、城下の橋等、 藩の御普請方が担当した工事を記した「承應元壬辰年より御普請所 覚」（文献 4、pp. 166 176）にむ見られ、藩御普請方が建設を担当 したと考えられる。「承應元壬辰年より御普請所覚」に寛文 4 年焼 失の御使者宿を建設したことを示す記事が見られないことから、藩 御普請方が御使者宿を建設していたとすれば、この御使者宿の建設 は承灾元年（1652）以前にまで遡ると言えよう。

寞文 5 年再建の御使者宿は延宝 4 年（1676）12月に類焼する（文 献 $3 、$ p. 181）が、後述するように翌延宝 5 年10月には、支藩松山藩 主が一日市町御使者宿に宿泊しているので、延宝 5 年には再建され ていたと判断される。貞享 2 年（1685）7月4日夜に再び類焼し、 翌 3 年に再建されたが、さらに、安永 7 年 (1778) に再び焼失し

（文献 8、p. 119）、その後再建はされなかった。

以上の経緯をまとめると、以下のようになる。

第 I 期 : 承応元年（1652）以前の建設～寛文 4 年（1664）の焼失

第 II 期 : 宽文 5 年の再建 延宝 4 年 (1676) の焼失

第而期 : 延宝 5 年の再建〜貞享 2 年 (1685) の焼失

第IV期 : 貞享 3 年の再建 安永 7 年 (1778) の焼失

ところで、鶴岡城下一日市町に御茶屋があったとする記録も見ら れ、宽文 7 年（1667）5月18日に幕府より派遗された巡見使 3 名が 鶴岡に到着し「右御巡見御宿、左之通、一日市町御茶屋、七日町疋 田多右衛門、同町伊勢屋藤右衛門」（文献 2、p. 237）之書加てい る。これに先立って、巡見使宿舎の用意に関して、同年閏 2 月に

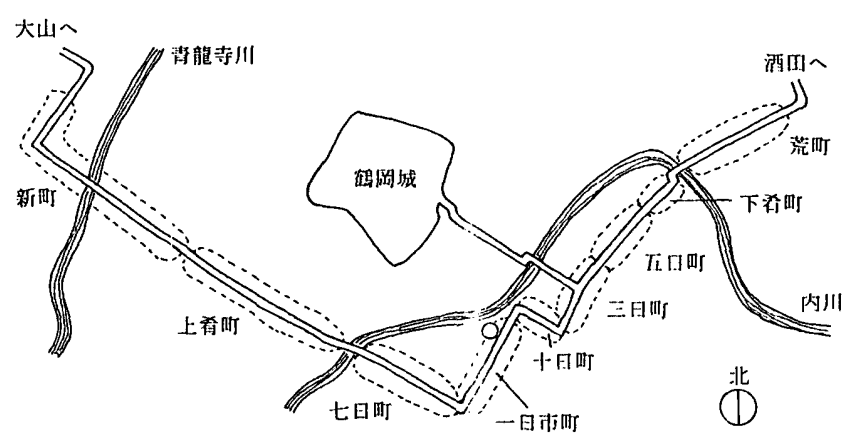

図 2 鶴岡城、羽越街道、 御使渚宿の位置

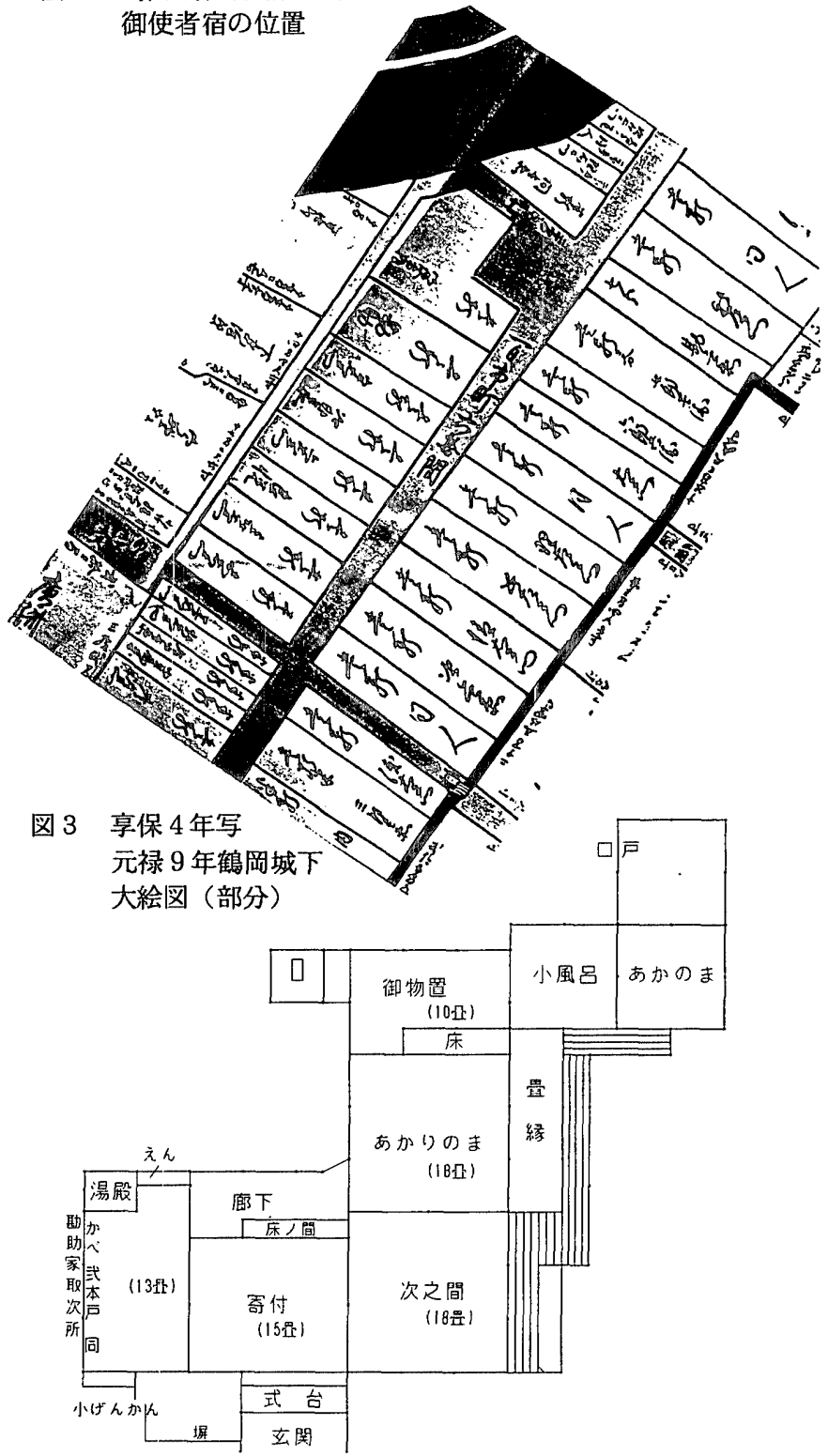

図 4 一日市町御使者宿御指図

「右御巡見使御下向二付、追々被仰付候、御普請所左之通」（同、p. 229）とある中に「一日市町御使者宿御修覆、七日町伊勢屋藤右衛門 家修覆、同町多右衛門家修覆」とある。閏 2 月から 5 月までの間に 巡見使宿舎を変更した記録は見出せず、御茶屋と御使者宿とは同一 のものを指すと考えてよい。この他、松山藩主の宿舎に関する記録、 および、前述の宇治勘助家に関する記録に見られる御茶屋む、以下 に述へるように、御使者宿と同一のものと考えられる。 


\section{$2-2$ 御茶屋（御使者宿）の利用者}

庄内藩主と姻戚関係にある支藩松山藩主は、鶴岡城へ登城する際、 一日市町の御使者宿を利用していた。延宝 5 年（1677）10月 3 日に 「石見守殿（松山藩主）鶴岡江御出、午之上刻一日市町御使者宿江 被成御座」（文献 3、p. 198）とあり、御使者宿に宿泊し、翌 4 日に 松山へ帰城している。

この時の庄内藩側の対応の様子を見ると、石見守が御使者宿へ到 着する際には「御町奉行石沢作左衛門御使者宿二罷在、門迄罷出」

（同）とあるように、町奉行が出迎えのため事前に御使者宿に出向 いている。また、「御使者宿二而御馳走人、御使番平野八左衛門、 坂部九兵衛」（同）亡あって、御馳走人が派遣されていた。石見守 が鶴岡城へ登城し、夜に御使者宿へ戻った際には「三日之晚、御家 老、御組頭御使者宿江御見迴申上ル」（同）とあるように家老等が 訪れている。

松山藩主はその後も同様に鶴岡に来ているが、元禄 6 年（1693） には「酒井石見守様一日市町御茶屋御休被遊候」（文献 4、p. 745）、 宝永 2 年 (1705) には「酒井石見守様市郎兵衛様此方様江御出御登 城有之、石見守様御宿一日市町御茶屋」（文献 $5 、$ p. 305）とある。 この時、藩士助川弥三右工門が「御馳走役被仰付相勤」（文献 $4 、$ p. 745）とあり、これは延宝 5 年に御使者宿に派遣された平野八左衛門、 坂部九兵衛の 2 名の御馳走人と同じ役と考えられ、御茶屋は御使者 宿と同一のものとしてよい。

巡見使の宿泊については、前述の寞文 7 年（1667）の記録から、 御使者宿と有力商家 2 軒とが 3 名の巡見使の宿泊に用意されていた。

また、延宝 6 年（1678）5月に、温海温泉で湯治していた亀田藩 主岩城伊豫守が居城のある龟田へ帰る途中"7) の記録として、「同十 一日早朝、伊豫守殿温海御立（中略）同日川井佐左衛門之申仁、鶴 岡江来着、疋田市右衛門、加藤太左衛門宅江、河上四郎右衛門先立 二而帠出、同日市右衛門、太左衛門、御使者宿江為御礼罷出る」

（文献 3、p. 229）とある。川井は文意から伊豫守家臣之考えられ、

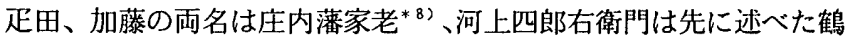
岡町大庄屋である。伊豫守が通行の挨拶として庄内藩家老宅へ使者 を派遣し、これへの返礼として両家老が御使者宿にいた川井のもと を訪れた、という状況であったことが知られる。この例では、御使 者宿が他藩使者の休息、宿泊のためではなく、接待のために用いら れており、興味深い利用方法と言える。

これら以外の利用者としては、延宝元年（1673）6月15日に「高 野道入老、鶴岡江参着、一日市町御茶屋江在留すと云々。右道入老、 十八日鶴岡出立」（文献 $3 、$ p. 122） と幕府関係者高野道人 ${ }^{* 9}$ ) 3 泊した記録が見られる。

また、庄内藩主は、鶴岡城の極めて近くに位置する一日市町御茶 屋を利用する必然性がそしく、そうした記録も遺されていない。一 方、御茶屋が存在しなくなった安永 7 年以降、それまで御使者宿を 利用していた松山藩主、巡見使等は、代わりにどのような施設を用 いていたか、を示す資料は乏しいが、例えば、天明 8 年 (1788)に 来藩した巡見使 3 名の宿所は地主長右衛門、奥井長兵衛、林駒之助 とされ（文献 $8 、$ p. 56）、先に述へた寛文 7 年の疋田多右衛門、伊 勢屋藤右衛門之同様の有力商家が用いられたと考えられる。

$2-3$ 御茶屋（御使者宿）の平面構成

庄内藩御普請奉行配下の大工棟梁の職を代々勤めた家柄である小

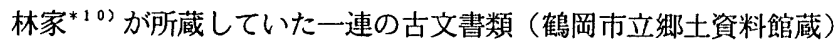
の中に、貞享 3 年 (1686) の「一日市町御使者宿御指図」と題され た図が遺され、図4 はそれを基に描いたものである*11)。貞京 3 年 は先に述へた如く前年焼失した御使者宿の再建の年であり、この図 には第IV期の建設当初の姿が描かれていると考えてよい。しかし、 これ以外の第 I 〜 III期の平面構成を知り得る史料は見出されていな い。また、貞享 3 年は先に述へた元禄 9 年の町絵図、延宝 4 年の御 水帳とほぼ同じ頃に当る。

図 4 によって御使者宿の平面構成を見ると、床を備え、曽縁、御 物置、小風呂等を付属させた「あかりのま」亡次之間とからなる座 敷、並びに、休と式臺とを備えた寄付等が描かれている。方位は記 されていないが、式臺の面する方向が羽越街道、即ち東になろう。 先に示したように、この頃の御茶屋は図 3 に描かれる間口 9 間の敷 地に建てられていたと考えられる。図 4 に描かれる建物の間口方向、 即ち、図で左右方向の規模は 9 間以上になり、水帳に記される間口 9 間でははみ出すが、敷地図では後方で右手に広がる形となってい るので、この部分に建てられていたとすれば、矛盾はない。寄付の 左手の部屋には名称が記されていないが、その左端部分に「勘助家 取次所」之記され、この部分 3 間には 1 間ずつ、上から「かべ

「武本戸」「同」と書き込まれている。図 3 からも分るように、左 隣の敷地は勘助居屋敷である。

原図には図 4 の他に、余白部分に「天井高サ之覚」として各室の 天井高が上間御次之間、上之間御床、御寄付、勘助家之取付ノ間、 御廊下の 5 項目に分けて記されている。これらの部屋名と図 4 の書 き込みとを対照させれば、「あかりのま」が上之間に、寄付左手の 部屋が勘助家之取付ノ間に、それぞれ該当することが理解される。

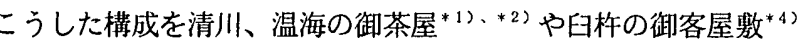
と比較すると、清川等の例では、御茶屋、あるいは、御客屋敷とし ての機能を果すに当って不可欠な御居間部分、番所広間部分、台所 部分から構成されていたが、これらの内、御居間部分、および、番 所広間部分に相当する部分は図 4 でも読み取ることが出来るのに対 し、台所部分は見出すことが出来ない。

一方、宇治家に遺された史料によれば、第IV期の御茶屋に関して、 安永 7 年 (1778) 焼失時に「貞享三年宙年御茶屋御普請被仰付候節、 拙者居屋敷之内、五間余并居宅之分も御勝手御座敷相成候様被仰付、 是迄御用立罷在候」（文献 $8 、$ p. 119）とある。前述のように御茶屋 は御使者宿と同一のものと考えられる。これは、安永 3 年 (1774) の同家の史料に「殊二自分居屋敷之内五間御用達罷在候二付」（文 献 9、p.57）とあるのに符合し、さらに「右御茶屋之内勘助居屋教 も六間二十五間御用立指置候次第」（同、p. 58）とある。勘助の居 屋敷（之内）とされる居宅と上記の五間、六間二十五間との関係が 明確でないものの、これらの表現と図 3、4 とを併せて考えれば、 隣地の勘助屋敷内の建物が図 4 の勘助家之取付ノ間に戸を介して接 続し、休泊利用時の「御勝手」、即ち、台所部分としての機能を果 たしていたと判断される。そして、この台所部分は勘助家之取付ノ 間によって番所広間部分に接続していたと同時に、さらに廊下によ って御居間部分にも接続していた。

2-4 御茶屋（御使者宿）の建設・維持管理

宽文 5 年（1665）の御使者宿再建は藩御普請方が担当したことは 既に述べたか、「承應元壬辰年より御普請所覚」には、前述の寛文 
表 1 勘助居家、御茶屋長屋、御茶屋井屋の建設。修復に関する年表

\begin{tabular}{|c|c|c|}
\hline 勘助居家 & 御茶屋長屋 & 御茶屋井屋 \\
\hline & & $\begin{array}{r}\text { (4)延宝 7（1679）一日市町御蔡屋井屋立直 } \\
\text { （文献 4、p. 176） }\end{array}$ \\
\hline 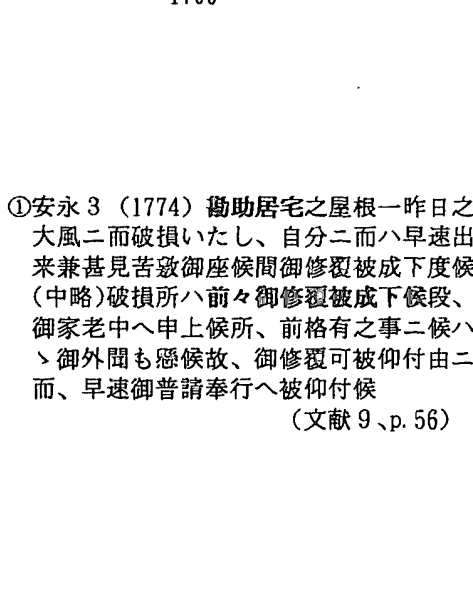 & 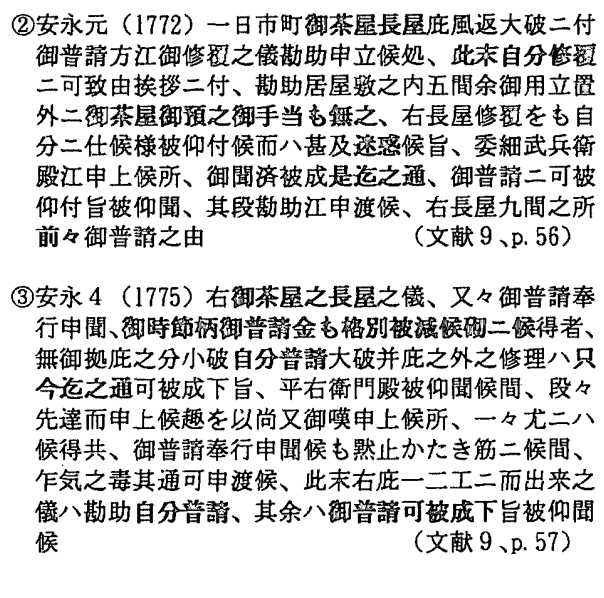 & 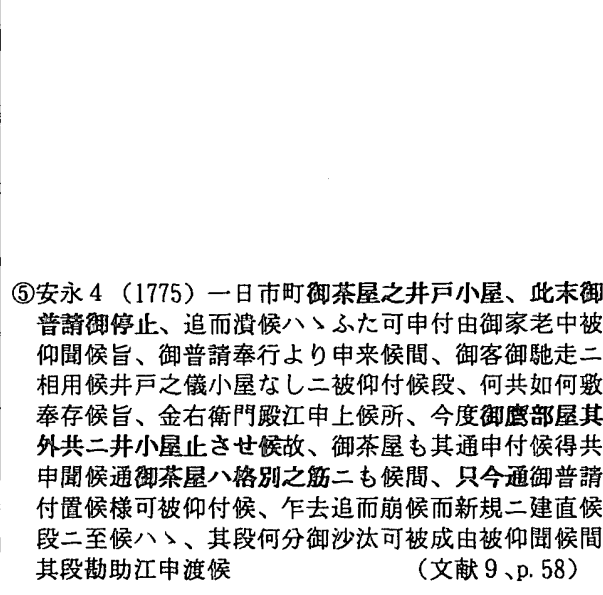 \\
\hline
\end{tabular}

\begin{tabular}{|c|c|c|c|c|}
\hline No & 標題 & 年号 & 内容 & 寒き込み、備考 \\
\hline (1) & $\begin{array}{l}\text { 湯田川村御茶屋指図控 } \\
\text { 田川御茶ヤ指図 (瑟) }\end{array}$ & $\begin{array}{c}\text { 貞享 } 3 \text { 年11月11日 } \\
(1686)\end{array}$ & 御茶屋平面図 & $\begin{array}{l}\text { 右側寒手部分の表現 } \\
\text { か簢略 }\end{array}$ \\
\hline (2) & なし & 宝永 5 年 & $\begin{array}{l}\text { 治部家、御茶犀、七左衛門家 } \\
\text { 兵衙家町亚平面図、着色 }\end{array}$ & $\begin{array}{l}\text { 「御住居かへ」 } \\
\text { 貼紙 }\end{array}$ \\
\hline (3) & 湯田川村御絵図 & $\begin{array}{c}\text { 宝永 5年 4月 5日 } \\
(1708)\end{array}$ & $\begin{array}{l}\text { 集落配置図（御茶屋と和泉治 } \\
\text { 部のみ平面图） }\end{array}$ & 「小林瀬左衛門控」 \\
\hline (4) & なし & 宝永 5 年 4 月 18 日 & 御茶屋平面図 & 「小林瀬左衛門控 \\
\hline
\end{tabular}

7 年の巡見使に対応する「一日市町御使者宿御修覆」（文献 4、p. 1

70）等が記されているので、修復も同様に御普請方によって行われ ていたと考えられる。また、第IV期の御茶屋の建設年である貞享 3 年（1686）の絵図が小林家に所蔵されていたことも、この建設を藩 御普請方が担当していたことをうかがわせる。第IV期の御茶屋は安 永 7 年に焼失するか、この時の記録に「御茶屋諸道具之内、盢廿五 枚、から紙十武枚、板戸七枚焼残之分、右掛り御役人臯へ相渡ス」

（文献 8、p.118）とあるように、当然藩の所有物であった。しかし、 御茶屋建物は宇治家敖地内の建物之結合されているので、藩御普請 方が建設、修復を担当する範囲が問題となる。

御茶屋本体以外に、関係する建築物として、先に挙げた勘助居家 の他、御茶屋長屋、御茶屋井屋が見られ*12)、これらの建設・修復 に関する記録をまとめて表 1 に示した。

まず、勘助居家の修復については表 1 (1)によれば藩の御普請方が 担当しており、これは「前々」とあって従来からのことであった。 次に長屋の修復に関して、(2)には「是迄」あるいは「前々」は藩が 修復を担当していたが、「此末」つまり今後は「自分修覆」するよ うに言われ「迷惑」だと反論して従来通り藩の担当とさせた経緯が 記されている。その 3 年後の(3)では、修復の負担を「庇之分小破」 は「自分普請」、「大破并庇之外之修理」は「只今迄之通」り藩の 担当という取り決めが成立している。最後に御茶屋井屋については、 (4)は先の「承雇元壬辰年より御普請所覚」に記されることから御普 請方が建設したことが知られるが、(5)ではやはり「此杢」は御普請 方で担当することは止めると通告され、交渉して今回は「只今通」 つまり従来通り御普請方で担当するが、今後については保障の限り でないという合意に達している。
これら表 1 に見られる建設・修復の記事は、限られた時期のもの であること、相手側の藩御普請方の史料が遗されていないこと等の 問題点があるものの、概ね、安永年間以前までは、勘助居家、御茶 屋長屋の修復、御茶屋井屋の建設を藩御普請方が担当していたが、 この時代になって勘助の負担で行うよう藩側が主張し、勘助側が

「御茶屋八格別之筋」（5) 等の理由を付けて前例通りの扱いを要 求している状況か理解される。こうした藩側の措置の背景には「御 時節柄御普請金も格別被減候砌二候」（3）等とされるように、藩 財政の逼迫*193 があったと考えられ、安永 7 年（1778）に第IV期の 御使者宿が焼失の後再建されなかったことも、同様の理由からであ ったと推察される。さらに、こうした施策は「今度御照部屋其外共 二井小屋止させ候」（5)）とあるように、御茶屋のみならず、藩の 施設全般に対して取られた措置であることが分る。

日常的な維持管理については、「御茶屋御預之御手当も無之」

（2)）、あるいは、「勘助御茶屋相守候二付、御手当も無之」（文 献 9、p. 57）とあることから、南隣の大庄屋宇治勘助家が担当して いたことが知られる。それに対する手当が宇治家に支給されていな かったと記されている。

\section{3. 湯田川解蔡屋}

3-1 湯田川温泉の概要と御茶屋の位置・変遷

湯田川は鶴岡市の南西約 $6 \mathrm{~km}$ にあり（図 1 ）、田川湯村とも呼ば れた。湯田川御茶屋を描いた絵図は 4 枚遺されている。いずれも図 4 之同様、小林家の史料であり、年代順に(1) (4)の番号を付けて表 2 に示した。この内、図 5 に示す(3)からは町並の様子を知ることが でき、中央に水路を設けほぼ南北に延びる街路を中心に集落が形成 


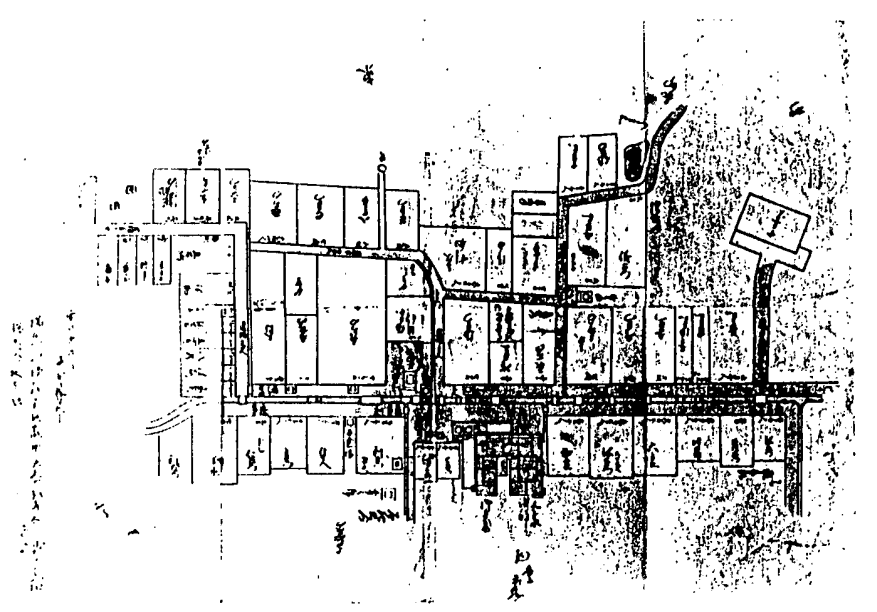

図 5 湯田川村御絵図（表 2 (3)、左: 全体、右: 部分)

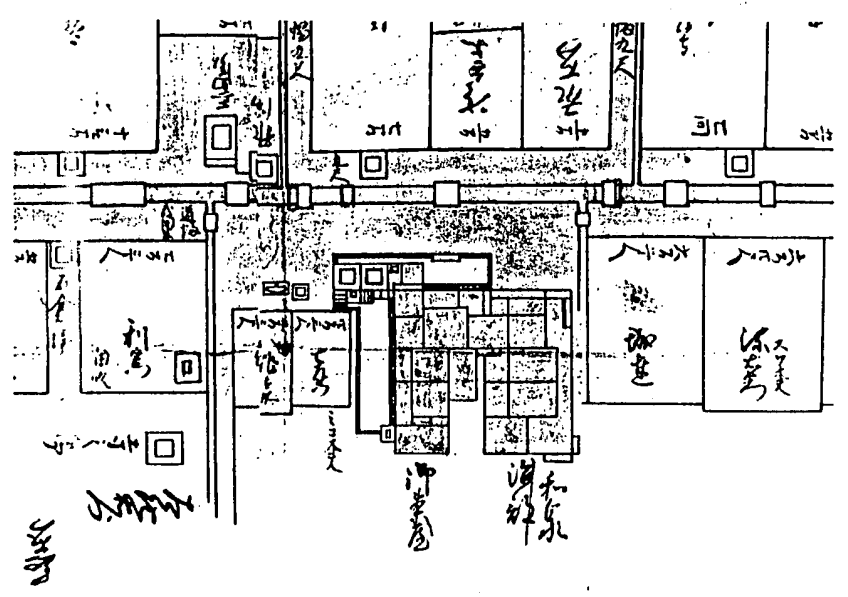

され、左手北が鶴岡方面となるが、この街路形態は現在に受け継が れている。道の西側に御茶屋が描かれ、隣には高札が、斜め向かい には、現在も公衆浴場として同位置に存在する正面湯が描かれ、道 幅もこの付近で広がり、位置も集落中央部に当る。しかし、後の天 保 3 年（1832）の「羽州荘内田川温泉図」（長福寺藏）には、図 5 で御茶屋とされる位置は薩广正とされていて御茶屋は見られないこ とから、天保 3 年以前に廃止された可能性が高い。現在この位置に は、近年まで御殿旅館と名乗っていた旅館がある。

鶴岡の章で示した、寛文 7 年（1667）の巡見使派遣に対応した 「右御巡見使御下向二付、追々被仰付候、御普請所左之通」に「湯 田川村御茶屋建」とあり、巡見使派遣を契機に寛文 7 年に建設され たことが知られる。この時巡見使が湯田川御茶屋を利用したことを 示す史料は見出せないが、建設の経緯からして利用したものと考え られる。

庄内藩主はこれ以前から湯田川へ湯治に赴いており、寛文 3 年 （1663）には、温海温泉での滞在の帰路、9月20日に「湯田川村江 御止宿遊ばさる、御宿治部太夫」（文献 $2 、$ p. 161）、翌21日「此日 湯田川村御発駕、御帰城遊ばさる」（同）とある。また、御茶屋建 設の後、延宝 7 年 (1679) には、鶴岡の章で示した「承應元壬辰年 より御普請所覚」に「湯田川村御茶屋湯屋共御修覆」（文献 4、p. 1 76）之記されている。寛文 7 年の建設の記事もやはりこの覚書きに 見られ、建設、修復いずれも藩の御普請方が担当したと考えられる。 しかし、その後の修復や利用状況を示す資料はそしい。

3-2 湯田川御茶屋の平面構成

表 2 に示す絵図 4 枚の内、(2)には貼紙が遺され、現在は糊がはが れているが、容易に貼られていた位置を探し出すことができ、貼紙 前の図と貼紙後の図とを共に知ることができる。貼紙前は(1)に、貼 紙後は(3)(4)にそれぞれほぼ一致することから、宝永 5 年に改築され たと判断してよく、(2)の裹に「御住居が」書き込まれているこ とも改築を裹付ける。

まず、(2)の貼紙前の平面を基に図 6 を描いだ14)。全体がコの字 型の平面であり、上侧が道となる。主要な部屋の名称は記されてい ないが、床を備え裏手に御納戸を持つ部屋が、清川、温海の御茶屋 絵図で御居間と書き込まれた部屋に相当しよう。この部屋から始ま る座敷部分を囲む入側から、縁を介して表側にある御湯に連結され、 この点も温海御茶屋と同巧である。左右を連結する形になる中央の



図 6 湯田川御茶屋（表 2 (2)貼紙前、部分）



図 7 湯田川御茶屋（表 2 (2)貼紙後、部分） 
部屋の縁には中ノ口が付せられている。一方、中ノ口とは別に、道 路側に迴された塀に御門が描かれる。建物の右端には大戸、通り土 間等の書き込みが見られる。そして、(1)むほぼ同内容である*15)。

(2)（図6) では描かれる建物の名称として、左側に御茶屋、右側 に治部家と書き込まれ、この治部は、先に挙げた、御茶屋が建設さ れる前の寛文 3 年に藩主が宿泊した家として挙げられていた「治部 太夫」のことであろう。(3)（図 5 ）にも同様に左に御茶屋、右に和 泉治部之書き込まれ、和泉治部は治部、治部太夫と同一人物で「領 主御入湯の節は社家和泉といへる者の内湯に入らせ給う故に御物に て建替修復等あり、是を御殿の湯といふ」（文献12、p. 2ノ10）とあ る社家和泉に該当しよう。

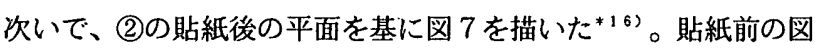
6 と比較すると、御湯の数が增やされ、表側一增築されて御休息間、 御次が新設され*17)、また、入隅部に御納戸も増筑されている。御 次詰座敷、御用部やの書き込みから、これら 2 室は扈従する家士の 詰所として用いられていたことが分る。

図 6、7に見られる建物は、御茶屋として利用される場合は、左 側が御居間を含む書院座敖で藩主等が利用する部分、右手が「なか し」を備えた通り土間を中心とした台所部分であり、両者を連結す る部分は玄関が付せられた家士詰所部分で、図 4 の寄付に相当しよ う。同時に、右手部分が通り土間を持つ町屋平面と理解されること、 (1)で右側裹手部分の表現が簡略化されていること*15) 等を考虑すれ ば、左右両部分の境界は明確でないものの、(2)(3)の書き込みに見ら れるように左側が御茶屋、右側が治部の居家であったと考えられる。 従って、藩主等の休泊に必要な3つの機能が御茶屋と治部家とを結 合したものの中に振り分けられていたと言える。

また、道から建物へ入る場合、御門から入って縁に上がる動線、 中ノ口から入る動線、通り土間の大戸口から入る動線の 3 喠類が読 み取れるが、これらの使い分けについても不明である。

\section{4. 藤嶋御条屋}

\section{1-1 藤嶋の概要と御茶屋の位置。変遷}

藤鴄は藩主参勤交代路上、鶴岡城下と清川との中間に位置してい た（図 1)。清川御茶屋か陸路と水上路との乗換地にあって藩主参 勤交代時の宿泊に主に利用された*1) のに対し、藤嶋御茶屋は専ら昼 食時の休鄎に用いられ、利用者も、藩主、支藩松山藩主、巡見使等 が記録に見られる*18)。

藤䲺御茶屋が文献に初見されるのは、延宝元年（1673）の「今度 余目御茶屋引取、藤鴄村江御茶屋立之儀、奉伺候処、藤鴄村江御茶 屋建可申旨被仰出、絵図指出候様、中村七兵衛二申渡」（文献 3 、 p. 116）であり、余目御茶屋を移築したことが知られる*19。余目

（図 1 ）は酒田から鶴岡方面へ南下する羽越街道が清川方面への道 を分岐する所である。ここの御茶屋については万治 2 年（1659）に 「余目村御茶屋建」（文献 $4 、$ p. 167）とある*20)。余目から移築さ れた御茶屋は「（延宝 5 年）藤嶋村御茶屋御門共二建、延宝八年申
六月廿四日之夜焼申候、但御門残申候」（文献 4、p. 174）とあるよ うに延宝 8 年 (1680) に焼失した。その後、貞享 3 年 (1686) に高 㚼御殿*21)の一部が藤嶋に移築されて明治維新まで御茶屋として用 いられ、明治 5 年に氏族授産のため、鶴岡の南東約 $10 \mathrm{~km}$ の松ヶ岡に 開瓭場が開設されるに際して、事務所兼幹部の集会所として用いる ために一部が移築され、松ヶ岡本陣と呼ばれた。この 2 度の移築の 経緯は、すでに文献14 pp. 28〜30に詳説され、また、現在も松ヶ岡 にある遺構の調査結果も同書に報告されているので、本稿では、藤 嶋に建てられて御茶屋として用いられていた期間に限って、対象と したい。

藩政期の藤嶋町は、図 $8^{* 22)}$ に示すようにほぼ北から南へ 状に延びる道沿いに町並が形成され、南側から上町、中町、下町に よって構成されていた。北へ進めば余目、松山に、南に進めば鶴岡 に達し、集落北端で清川に向かう道を東に分岐していた。御茶屋は 下町の南端、街道の西側（図 8 ○印）に設けられていた。

\section{4-2 藤嶋御茶屋の平面構成}

藤嶋御茶屋を描いた絵図は 5 枚見出され、これらを表 3 に、ほほ 年代順に(1)〜(5)として示した。(4)は致道博物館蔵、他は先に述へた 小林家の史料である。これら 5 枚は(1)～(3)、および、(4)(5)の 2 グル 一プに大別される。

まず、(1)は日付から、高畑御殿から移築された直後の御茶屋を描 いたもので、これを基に図 9 を描き"23)、併せてその原図も示した。 (2)も同様の時期のもので建物は(1)にほぼ一致し*24)、これを基に図 10 を描いた ${ }^{* 25}$ 。敷地全体が描かれ、御茶屋御門が面する道に「藤 嶋下町」の書き込みが見られる。(3)に描かれる建物も(1)(2)に一致す る*26)。

図 9 を見ると、図中に寄付、御湯殿、御物置等の書き込みがある 他、原図の余白書き込みに「上之間、御次之間迄新木を立……と あることから、最む奥の床と押入とを備えた部屋が上之間に、その 手前の部屋が御次之間に当ろう。このような間取りは図 4 に示す鶴 岡の御茶屋（御使者宿）に酷似し、休泊時に必要な3つの機能の内 台所を欠く構成である。一方、図10を見ると、建物は南側梦地（図 では左側）との境界線に接して建てられ、しかも、建物が接するこ の部分とその周辺には、道側を含む 3 方向の境界とは異なって、土 手や塀は描かれていない。さらに、隣地との境界線上の部分を図 9 で見ると、「取次」「古四本戸」と書き込まれている。この状態も、 図 4 の「勘助家取次所」と書き込まれる部分に酷似している。従っ て、鶴岡の御茶屋と同じ様に、敷地境界の仕切り方の弱い南側に、 「取次」とある筒所の戸によって接続される他の建物があり、そこ を休泊時の台所として用いていた可能性が高い。

次いで、(4)(5)は書き込まれている年号も近接し、描かれる図もほ

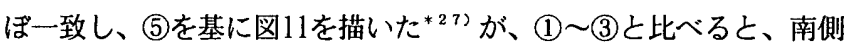
に敷地、建物が付加された形に描かれている。図 9 の御物置が図11 では御料理方と、その南に接する部屋に御臺所と書き込まれ、付加 部分には土間、勝手等と書き込まれ、御菿所と勝手との境 2 間分に

表 3 藤嶋御茶屋絵図資料一覧表

\begin{tabular}{|c|c|c|c|c|}
\hline No & 標題 & 年号 & 内容 & 書き込み \\
\hline (1) & 藤嶋御茶屋御造作付 & 貞享 3 年（1686） 5月 8日 & 御茶屋平面図 & 「小林瀬左衛門控」 \\
\hline (2) & 藤鴄御茶屋指図 & 貞敦 3 年（1686） 5 月12日 & 御茶屋配畺平面図、着色 & 「小林瀬左衛門控」 \\
\hline (3) & 藤嶋御茶屋 & 寅 5月23日 & 御茶屋平面図 (一部梁伏) & \\
\hline (4) & 蕂崔御茶屋絵図扣 & 天保14年（1843）5月 & 御茶屋配置平面図 & 「樏梁小林喜助改」 \\
\hline (5) & 藤嶋御茶屋 & 嘉永 3 年（1850）6月 & 御茶屋配㯰平面図 & 「茂平太扣」 \\
\hline
\end{tabular}




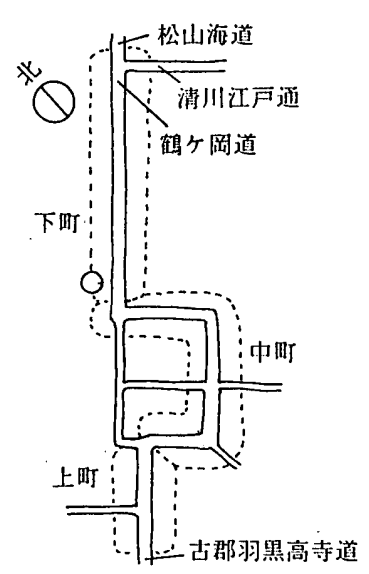

図 8 藤嶋町略図
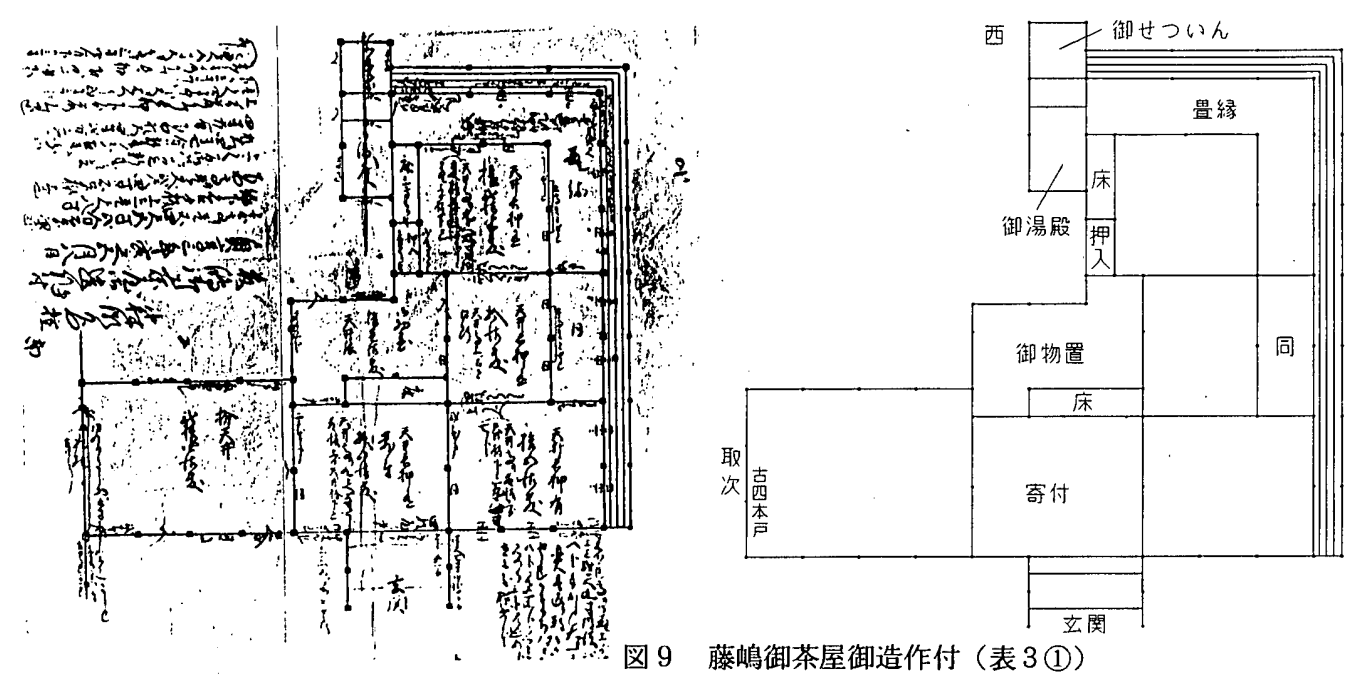

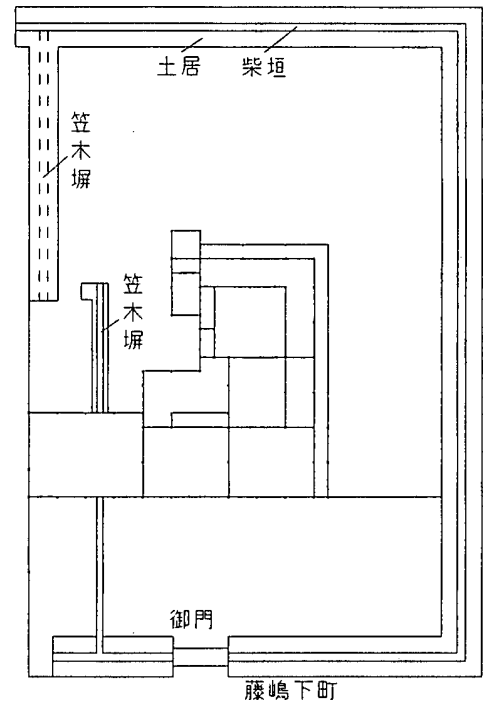

図10 藤嶋御茶屋指図（表 3 (2)）

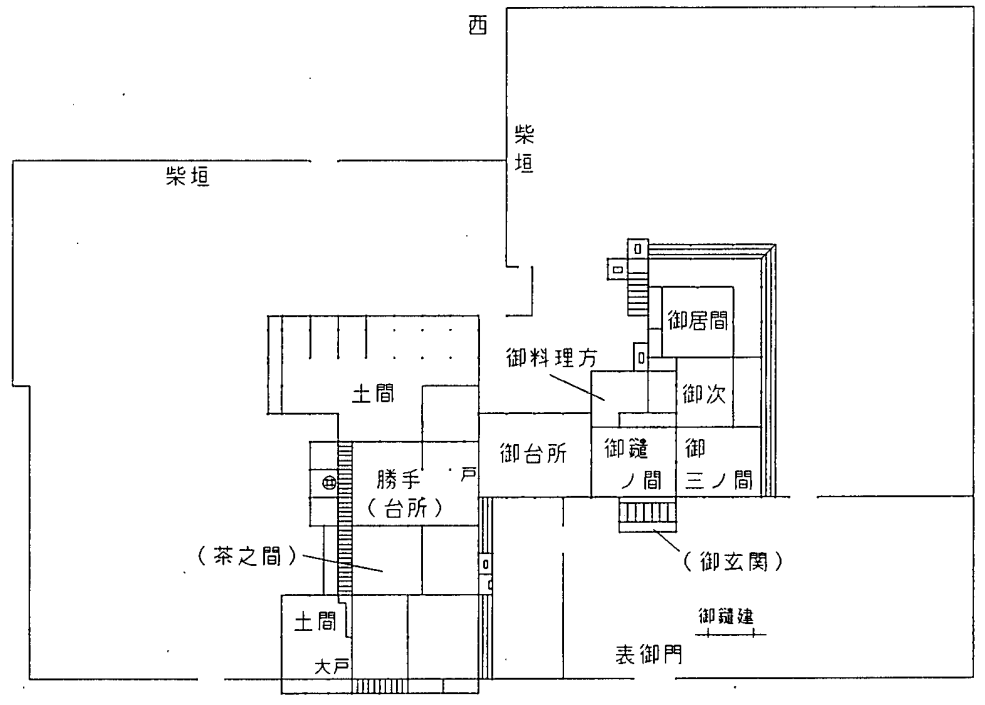

図11藤嶋御茶屋（表 3 5)

の違いから生じるか、が次の課題となろう。同時に、御茶屋に隣接 する民家内が御茶屋利用者の台所として用いられた場合、通常の隣 家の生活に支障をきたすことになり、それにどのように対応したか、 が問題となるが、それを知り得る記録は遺されていない。

前稿では御茶屋の建設、廃止の理由を示す資料が見出せなかった が、本稿では、湯田川御茶屋の建設理由、および、安永 7 年 (1778) の鶴岡御茶屋（御使者宿）の廃止と1700年代後半の藩財政逼迫との 関連性を指摘することができた。鶴岡の御茶屋と同様に藩御普請方 によって建設、修復されていた清川、温海の御茶屋がそれぞれ文化


求め得る。

左内藩内には上記 5 箇所以外の場所にも御茶屋が設けられ、また、 温海に見られたように本陣と称する施設を休泊に利用する例む見ら れた ${ }^{22)}$ 。今後は、れらを含めた藩全体の宿泊施設を体系的に把握 することが必要とされよう。

[謝辞] 本稿をまとめるに当り、佐藤巧東北大学名誉教授にご教示 を賜り、また、資料閲覧に関し鶴岡市郷土資料館秋保良氏、長福寺 の協力を得た。付記して謝意を表したい。 
齐

1) 岡田悟、饭淵康一、永井康雄「庄内落における清川御茶屋について」 (『日本建筑学会計面系論文集』第 485 号、pp. 173 182、1996.7)


御本陣について」(『日本建築学会計画系論文集』第 500 号, pp. $229 \sim$ 236、1997.10)

3）丸山㺘成居日本近世交通史の研究』、吉川弘文館、1989、p. 90

4) 北野隆「目杵落の「御客屋敂」について」(『日本建勧学会大会学 微謝演梗概集 $\mathrm{F}$ 分冊』、pp.1551 1552、1994.9)

5 ）鶴岡城下図の図 2 ○印の位圈には御使者宿と書き込まれている例が 多いが、明和 7 年の羽州庄内鶴岡城下絵図(鶴岡市鄉土資料館葴)に は本陣とされている。現在この位圈は映画館等が建ち並ふ算華街とな り、旧時の面影を留めるものは进されていない。

6 ）延宝 6 年の鶴岡御城下御絵図（鶴岡市郷土資料館荿）には原則之し て武家屋敂、葴屋敂、寺院の數地のみが描かれているが、御使者宿敂 地屯同し扱いで描かれている。また、明和 7 年の絵図（注 5 ) ては、 敂地は、町奉行所、評定所、作事方会所等之共に、凡例て「役所葴屋 敂明き地」とされる色に登られている。

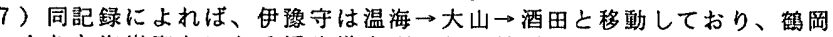
よりも海岸寄りにある浜街道を利用し、鶴岡城下は通過しなかったも のと思われる(図 1)。

8 ）文献10による。疋田市右衙門の屋散は三日町口にあり（同p. 540) 先に莌文 7 年に巡見使の宿泊に利用された七日町足田多右衡門とは異 なる。

9）「蓋し高野道入は公傜御同朋御坊主之数二而、何れ之御代毁、格別 昵近せし人にて」（文献 $3 、$ p. 122）とある。

10）永井康雄、飯淵康一「庄内落の普請・作事組織について」(『日本 建筑学会計画系論文集』第468号, pp. 171 180,1995.2）。図 4 原図に

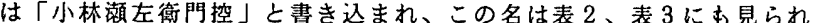
る。㖽左衔門、および、表 3 (5)に見られる茂平太は、共に小林家の樓 梁であり、各々(濑左衙門は 3 名) の存命の時期内に图に示される年 号が含まれている。また、表 3 (4)に見られる小林喜助は、同じ小林姓 であが、湤左衛門、茂平太らの家系とは別の、落御普請奉行配下の 職人て、文献18に「金七両二步三人扶持榑梁御徒格 小林喜助」と あるのに当る。

11）書き込みには原図に直接墨で書き入れられたものと卙り紙がされた あのとの 2 種穎が見られるが、利用方法の差異に対店した使い分比等 を示しているとは思われず、図4では区別せずに書き入れた。図4 に は平面槽成上主要な書き込みのみを記し、原図に詳細に書き込まれて いる間仕切（こしせうし、雨戸、かで等）、部屋ごとの「板天井長押 有」等の書き込みは、本文の説明に必要なむの以外は省略した。图 4 中の文字で㞧は略字の台を用いたか、これは図 6 以降も同様である。 また、大工植梁家の技術的な図に相応しく柱に○や $\triangle$ の記号が付され ているものがあるが、これらの記号も省略した。部屋の曽数は、原四 では拾八帖敫」等と記入されているのを图 4 ては（18異）として示 した。なお、図 4、6、7、9の4 図は縮尺を統一し、また、図10、 11はさらにその1/2に縮小して描いた。

12）長屋、井戸がどこにあったかは不明であるが、長屋に関しては「勘 助屋歌之分二長屋九間之所」（文献 $9 、$ p. 53）とある長さ 9 間の長屋 が表 1 (2)に言う「長屋九間」と同一のものとすれば、勘助の歌地内に あったことになり、安永 7 年の焼失時の記録に「御茶屋御長屋二罷在 候名子之者共、当時行所無之」(文献 $8 、$ p. 119) とあって勘助家の名 子が居住していたとされる状況にも矛盾しない。また、井戸は、通常 台所に近接してあることが多いのて、同粎に勘助の敬地内にあった可 能性が高い。

13）落財政の赤字は宝暦 5 年（1755）には 6 万両台、同 8 年には 9 万禹 台に達し、落では明和 4 年に酒田の桑商本間光丘を登用して財政の改 善を計った。天明初年にはをの効果が現れたが、引き続き彾锚等のた め落財政が好転することはなかった（文献 $6 、$ pp. 97〜113）。

4）(2)の原図には、さらにその左手に七左街門家、作兵街家の 2 軒の平 面が同粎の手法て描かているが、図6では省略した。なぜこの 2 幹を 含めて描かれているかは不詳でるるまた、七左衛門家の後部土間部 分をさらに後方に抬张した貼り紙も括され、同時に增筑工事が行われ たものと考えられる。原図には間仕切として、こしせうし、二本戸等 と書き込まれているか、、図6ては大戸の他は省略した。いろらは原図 に描かれていないか、图6には1に描加れるものを破線て描き入れ、 書き込みも(1)のあの（）を付けて書き入れた。

15）(1)では右側裏手の突出部分は、柱型も描かれず、書き込み類む全く されていない。これ以外の部分ては、浴槽、浴室の寸法等が(2)上上 詳細に淒き込まれている。また、(1)にも主要な部屋名は記されていな いが、图6 の御納戸が御物置に、中ノ口が御玄関に、通り土間が勝手 之通りとされている。

16）図 6 と同様に、原図の間仕切についての書き込みを省略し、また、 図 7 には(4)に描かれるいろり 2 箇所を図 6 と同様に描き入れた。(4)に は(1)に類似した詳細な書き込み（注15）が見られる。

17）御休息間という部屋名はこれ以外の御茶屋ては見られず、また、 の部屋の利用に関する記述は史料に見出せない。清川御茶屋の第的期 に見られた御曻間との共通性が考えられるが、御宊間や御休息間仕主 たる座敫である御居間より舆に位置するのが常であり、詳細は不明て ある。

18）落主酒井忠真が初入部の時、清川御茶屋に宿泊し、翌朝出発した後 「嵓島御茶屋江被為入、御弁当被召上候」（文献16）とある。また 松山落主は、鶴岡の項で述へた延宝 5 年に鶴岡に向かう途中に「藤鶝 御茶星御昼休」（文献 $3 、$ p. 198）とある。巡見使については注 30 参照。
19）「延宝四丙辰歳九月十一日ニこほし取、同五歳巳ノ歳藤島村御茶屋 二建」（文献 $4 、$. . 167） とあり、実際の移築は延宝 5 年 (1677) てあ った。中村七兵衙は宽文 3 年 (1663) 、同 7 年（文献 $4 、$ p. 168、171） の記録に御普請奉行として名が挙げられている。

20）現在も余目には、御茶屋のあった場所を中心に茶屋町の名前が遊さ れている。余目御茶屋の建築、余目に御茶屋が建設された理由、不用 になった理由、利用状況等は不明である。

21）高㚼御殿は鹤岡城下の高畑に、居城建設中の落主の仮御殿として設 けられ、居城完成後は下下御屋票」と屯呼ばれた（文献 $7 、 0.233$ ) が、 享保年間に給人屋敂に分等された（文献17、p. 16）。高畑御殿では宽 文年間までは「御小座影」「御涼所」等が建設され（文献 $4 、$ p. 169 , 172）ているものの、元禄 $7 、 8$ 年 $(1694 、 5)$ には建物の一部が取り填 されて、その材木が清川、温海の御茶屋や大餐寺に用いられており

（注 1、2）、この頃から下屋影としての機能が低下し余㮃の建物の 転用が行われたものと考えられる。

22）江戸時代中期の藤嶋絵図（文献15所收）に上る。図 5 と同様に、御 茶屋の降には「御制札」とある。現在は旧時の面影を留めるものは帛 されていない。

23）原図には建物のみが描かれ、歌地全体の様子までは描かれていない。 原図には部屋ごとに「天井長押有」「天井高州…」等と書き込まれ。 かべ、武本戸等の間仕切の状況が書き込まれているが、本文の説明に 必要なもの以外は図 9 では省略した。

24) (2)には(1)に描かれる玄関が描かれていないが、玄関は避にも存在 して後補とする形跡は見出せず、文献14にもそうした記齿は見られな い。書き込みの状況もほほ一致するが、图 9 に取次、古四本戸と書き 込まれる部分には、全く書き込みが見られない。

25）建物内の書き込みは图 9 とほほ一致するので省略した。柴垣、笠木 拼の部分は䀡紙であり、剥がれて紛失しているものの上から書かれた 文字の様子等から復原できる部分については、破線で描いた。

26) 「寅五月廿三日」とあるが、貞龺 3 年は寅年である。部屋名等は記 入されず、建具や間仕切を示す書き込みがされ、また、一部に梁伏図 む描加机、大工植梁家に伝わるに相応しい技術的な四てある。

27）(5の原図には塀の長さ、間仕切の状況を示す尹、マ卜等の書き込み があるが、図11では本文の説明に必要なもの以外は省略した。原図に は、票地内の空所に䦥所と外繁が、表御門前に番所が朱色で描き入れ られているが、図11ては省略した。また、図11で（）を付した書き込 み 3 箁所は(4)に書き込まれているものてある。

28）図11で御㠫所と書き込まれる部屋が図 9 でも台所として用いられて いたと解することも可能であるが、図 9 の原図のこの部屋には「疁之 上より迴りふち下迄」とあることから思敖きて天井があったことが分 り、図 9 に描かれる䇢囲には台所として不可欠な土間を欠き、台所部 分は含まれていないと解歌してよい。

29）䕠䲧の絵図（注22）ては、御茶屋の南側には通庵と記されているが、 この人物については不明であり、また、この絵図には敷地間口、骨行 等が記入されてなく、御茶屋とその南側敖地との関係を明確にするこ とがてきない。また、松っ岡には玄関より北側のみが移筑され、透構 からもこの点は解明出来ない。

30) 天保 8 年の「御巡見御用留」（鶴岡市郷土资料館蔵温海文書）には、 翌年の巡見使派遣に确えて、前回の天明 8 年 (1788) の巡見使が休泊 に利用した施設を書き出してあるが、それには「臀嶋村御体昼、御宿 御茶屋八郎兵街」とある。八郎兵衛については不詳であるが、同記録 の清川の項には「清川村御泊御宿、御茶屋専之助」とあり、ここに言

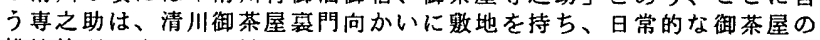
維持管理に当った百姓身分の御茶屋守尃助（注 1) に該当するのて、



参考立志

1）都丸広治『大泉紀年』上巻（『花内史料集』4、鶴岡市、1978，12）

2）都丸広治『大泉紀年』中巻（『荘内史料集』5、鶴岡市、1979, 3)

3) 都丸広治『大泉紀年』下巻（『荘内史料集』6、鹤岡市、1979.8)

4) 加藤正従『踓助編』上(山形県史編筑委員会編『山形県史』资料編 5 、登南堂書店、1961.3)


6、臂南堂書店、1961.3)

6 ) 斎藤正一『庄内落（日本歴史灌書43）』吉川弘文館、1990.10

7）『鶴岡市史』上巻、鶴岡市、1962, 11

8 ）『鶴ヶ岡大庄屋宇治家文書』上巻（『荘内史料集』11、鶴岡市、 1982.3)

9 ) 『鶴ヶ岡大庄屋宇治家文書』下巻（『荘内史料集』12、鶴岡市、 1983.3)

10）庄内人名辞典刊行会（財団法人致道博物館内）編『新編庄内人名辞 典』 1986.11

11）阿部整一、工藤謙次郎『元禄時代鶴岡城下大絵図』阿部久書店、 1976. 12

12）進藤重跑『出羽国風土略記」宝曆12（歴史図書社、1974）

13）佐藤政太『湯田川温泉（とうほく百科新書 1)』東北出版企画、 1983.10

14）『国指定史跡松r丘開脰場保存管理計画策定報告書』山形県羽黒町 教育委貝会、1994.3（建造物調㚗指尊は王井哲雄）

15）『藤岛町史』上巻、藤岛町、1 1965.3

16）「始而御入部之覚」、元䘵 2 （『式㼛旧貫』所収、鶴岡市鄉土资料 館藏)

17）高橋種芳『大泉掌故』（『荘内史料集』19、鶴岡市、1983.3）

18）「御普請奉行諸留控」（鶴岡市鄉土資料館蔵）

(1998年 2 月 6 日原稿受理，1998年 5 月21日採用決定) 